\title{
Czeladź city gate and walls in light of archaeological research
}

\begin{abstract}
Up until recently, Czeladź (Silesia, Poland) was generally believed to have been an "open" city, with no stone or brick fortifications. This belief persisted due to lack of historical sources from the period and insufficient archaeological research. In 2016, the authors of this article carried out archaeological investigations $70 \mathrm{~m}$ east of the Market Square. The investigations led to the discovery of two wall remains. The width of the first one was $1.40 \mathrm{~m}$. The wall was built from stones of various sizes, hewn only on the face side. The wall was added to another wall, $0.60 \mathrm{~m}$ wide at the foundation; however, the second wall was sunk into a compact layer of marl and clay, which reinforced it from its inner side. It was over $0.80 \mathrm{~m}$ wide, $2.07 \mathrm{~m}$ long and was preserved up to a height of $0.47 \mathrm{~m}$. Five layers of stone have survived. Two fragments of earthenware were discovered in the fill of this cut, dated to, respectively, between the $15^{\text {th }} / 16^{\text {th }}$ centuries and the $16^{\text {th }}$ century. A lime and sand mortar was used in the construction of both walls. This mortar is characterized by a grey and beige colouration and admixture of significant amounts of sand, limestone lumps, small brick fragments and charcoals. Such admixtures were used in the Medieval Period, and date the mortar to the $14^{\text {th }} 15^{\text {th }}$ century. Through architectural and cartographic analysis it can be said that these wall remains are remnants of an element of city fortifications, namely a city wall and a fragment of the eastern city gate. The opening of the presumed gate lies on the same axis as the exit from Rynkowa Street. The investigations provided further evidence for the fact that Czeladź had defensive walls. The research also proved, for the first time in source archaeological material, the existence of a city gate.
\end{abstract}

Keywords: Czeladź, Silesia, city gate, defensive walls

During the Medieval Period, cities chartered in cruda radice (i.e. on unsettled territory) were open cities, as during the initial stages of development they had no defensive fortifications. The process of formation of a city ended only when it was surrounded with fortifications. At that point, such a city was already firmly established and had a developed economic structure. It was not, therefore, a city in statu nascendi (Pierzak 2004, 187). Such delayed construction of

\footnotetext{
${ }^{1}$ Archaeological company „Eatus Alan Jaskot”; 18/24 Zielonogórska St., 40-710 Katowice, Poland; info@eatus.pl

${ }^{2}$ Provincial Heritage Monuments Protection Office in Katowice; 12 Francuska St., 40-007 Katowice, Poland; etrulia@op.pl

${ }^{3}$ Institute of Archeology, Jagiellonian University; 11 Gołębia St., 31-007 Kraków, Poland; rakkrzysztofarcheo@wp.pl
} 
defensive walls in relation to the moment of chartering occurred both within Silesia (Horwat 1986) as well as in Lesser Poland (Widawski 1973), Western Pomerania (Lukas 1974) and the New March (Kozaczewski 1989).

Czeladź (Fig. 1) likely also underwent a similar process (Malik 2010,6). The charter of this city did not survive. However, based on multiple pieces of evidence, such as the urban layout preserved since the Medieval Period and the amount of collected Peter's Pence attested in years 1325-1327, some researchers believe that the city was chartered in the second half of the $13^{\text {th }}$ century (Rajman 2012, 132-133). Until recently, both commonplace opinion and the literature held that Czeladź was an "open" city, with no stone or brick fortifications. The reason for this was twofold: first, there were no archaeologically recognized remains of a defensive wall above ground, and second, there were no source records from the Medieval Period indicating that the city had any stone or brick fortifications (Malik 2010, 6-9). The only mention of existence of a city wall in Czeladź comes from a very late period, the second half of the $17^{\text {th }}$ century. It can be found in the Inventory of goods of the Cracow Bishopric from 1668 (Inwentarz dóbr biskupstwa krakowskiego 1668), and reads as follows: This city at the very border of Silesia is situated by a river on unp...ed lands three miles from Siewior, was surrounded by walls on the rock, the fire destroyed both the city itself and the walls from wood houses were built anew...

The lack of source mentions meant that the explanation for this issue was expected to come from archaeological research.

However, it was only in 1997 and 1998 when large-scale excavations were carried out in Czeladź. One of their main goals was to find any potential remains of defensive walls. These works were led by a team from the Workshop of Archaeological and Conservation Documentation in Łódź (Andrzejewski et al. 1998; Pierzak 2012, 25-26). The excavations were carried out in two stages. The first stage began in 1997, when the works encompassed the churchyard area. Their main objective was to find remains of the first brick church. Despite the existence of surviving photographs of the old church and earlier non-invasive examinations using groundpenetrating radar, no major finds, apart from an 'ossuary', were discovered.

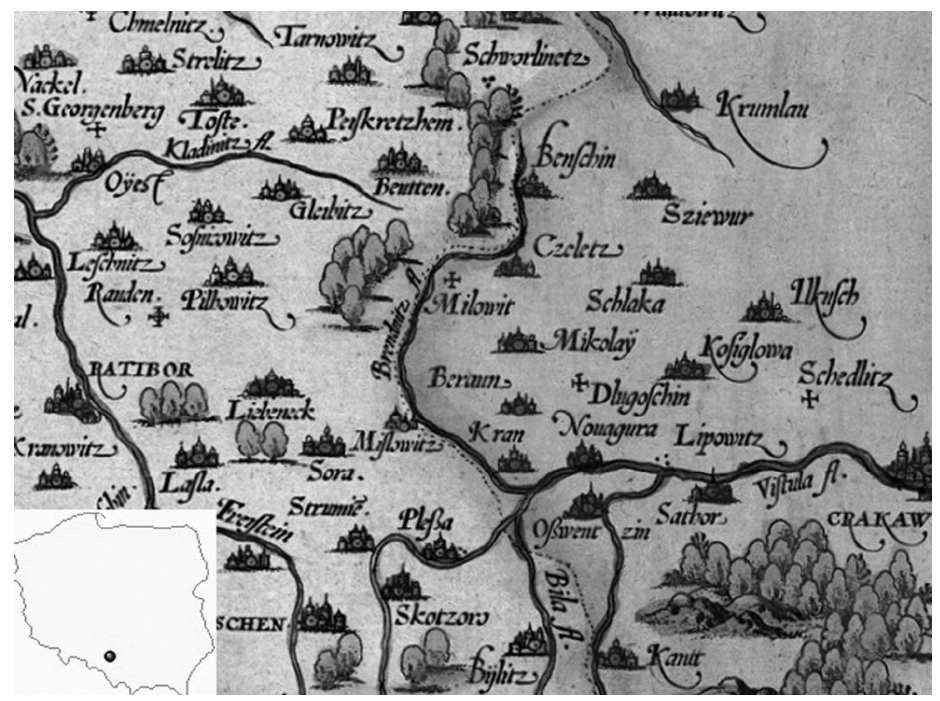

Fig. 1. Location of Czeladź in the Silesia region and in Poland. Fragment of map of Silesia from 1561 made by Abraham Ortelius (Ortelius 1606, 61) 
The second stage, which took place in 1998, was one of the largest archaeological projects carried out in Czeladź, as it involved setting up a total of 18 excavation sites with an aggregate area of $351.75 \mathrm{~m}^{2}$. Investigations encompassed the area of the retaining wall supporting the slope of the city hill from the side of Saint Stanislaus the Bishop and Martyr Church, where four excavation sites were established. Another three sites were set up in various locations of the Old Town, with a further six in the Market Square (Andrzejewski et al. 1998, 4; Pierzak 2012, 26-27). From the perspective of investigating city walls, the sites located by the retaining wall were of particular importance, as the researchers assumed that this wall may have containedremains of the medieval city wall. The main objective of works carried out at the time was to uncover these remains and determine their chronology (Andrzejewski et al. 1998, 4; Pierzak 2012, 26-27). The results of these works verified these theoretical assumptions (Andrzejewski 1998): despite the prior assumption of researchers that it may hide remains of the city wall, the retaining wall supporting the city hill contained no fragments older than the $17^{\text {th }}$ century (Andrzejewski et al. 1998, 40; Pierzak 2012, 27).

The next investigations related to the search for the city wall took place in April 2005, in the south-eastern part of the city, and were led by A. Andrzejewski from the University of Łódź (Andrzejewski 2005; Pierzak 2012, 31). It was suspected that the eastern part may have hidden remains of a city gate, while the southern part was expected to contain remains of the city wall (in the vicinity of the premises at 2 Staszica Street).

Two surveys were conducted in the eastern part of the city. Foundations of two buildings were discovered: one from the early modern period, the other from the contemporary period. To sum up the results of these investigations, it has to be said that they did not bring about the expected outcome: remains of neither the city gate nor the city's defensive wall were found. Archaeological works in the southern part of the city were not carried out as the owner of the premises refused to consent (Andrzejewski 2005, 4; Pierzak 2012, 34).

Significant progress in investigations related to the issue of city walls in Czeladź was only brought about by the archaeological research carried out in 2008 by A. Rogaczewska from the Muzeum Zagłębia (Museum of the Coal Basin Area) in Będzin. During the works performed around the church, on a strip of lawn on its north-eastern side, a fragment of foundation, running along the north-south line, was discovered. A wall fragment, possibly remains of a buttress or a pillar, adhered to this foundation. On the inner side, the wall ended with a stone layer. The width of the whole structure was over $2.5 \mathrm{~m}$. The foundation was laid through the area of an old cemetery and intersected two grave pits (Rogaczewska 2008b).

More foundations of stone walls were uncovered in the south-western part of the church. A newer wall, with a width of $1 \mathrm{~m}$, was found here, placed on the coping of a $1.90 \mathrm{~m}$-wide older wall. Although the newer wall most certainly does not hail from the Medieval Period, the older wall is unequivocally a structure of medieval provenance, as evidenced by its width and technique of construction.

During an archaeological supervision performed in the northern part of the Old Town, a $14 \mathrm{~m}$ long straight segment of an outer face of a wall was discovered. Its width at the foundation was $2.30 \mathrm{~m}$, with an outer berm width of $20 \mathrm{~cm}$. It was not possible to identify the inner berm. The northern side of the wall was set on sandy substratum and clay, while the southern side was set in the primary humus layer. A $2 \times 2 \mathrm{~m}$ trench was opened, adjoining the outer face of the wall. However, the foundation cut, which must have been set very shallowly, proved impossible to identify. A layer of primary humus with archaeological material dated to the $13^{\text {th }}-14^{\text {th }}$ century survived at the bottom of the trench. It was covered by a burnt layer, within which small iron clout nails were found. The width of the wall clearly proves its medieval origin. The height 
of the surviving fragment of the wall was approx. $0.5 \mathrm{~m}$ above the floor level. On the berm side, the wall was made of carefully selected, oblong, crushed limestone. The opus emplectum technique was used in its construction (Rogaczewska 2008a, 9-10). One of the authors of this article, J. Pierzak, suggested that the wall was created at the end of the $13^{\text {th }}$ century or at the beginning of the $14^{\text {th }}$ century, when Czeladź was part of the Duchy of Bytom, during the reign of Casimir II of Bytom. That duke, after taking over the Duchy in 1281, surrounded Bytom with a city wall, which was $2.60 \mathrm{~m}$ wide at the foundation, and built a castle with a stone residential and defensive tower at its core (Pierzak 2004, 187).

In 2008, an archaeological supervision was performed at the slope where Saint Stanislaus the Bishop and Martyr Church is located, led by A. Rogaczewska on behalf of the Scientific Association of Polish Archaeologists. The survey resulted in the establishment of five excavation trenches, with an aggregate area of 1 are, explored up to a depth of $1.50 \mathrm{~m}$ on average. Four of them were located along the presumed course of the wall: in the southern corner of the church plot, at the edge of the slope over Bytomska Street and at the opposite side of that street, at premises nos 18 and 20. The excavations led to the discovery of more remains of the defensive wall at three sites. At the site in the southern corner of the plot, the wall was $2.10 \mathrm{~m}$ wide. It was most likely demolished when the new church was built. The identification of cultural layers proved impossible on both the inner and the outer sides of the wall, as they were destroyed by demolition cuts and an added early modern building (Rogaczewska 2008b; Pierzak 2012, 36).

At the slope over Bytomska Street, where the church is located, this wall survived as two or three layers of stones bound with lime mortar. In the case of this wall, it was possible to observe fragmentarily preserved stratified deposits (Rogaczewska 2008b).

On the other side of Bytomska Street, at premises no. 20, a trench was opened which intersected the yard of a residential house. As works performed at this site yielded negative results, the site was moved to premises no. 18. Here, the inside of a stone wall was discovered, but with neither an inner nor outer face. The leader of the works believes that these may be the remains of a medieval defensive wall; this is suggested by the direction in which the wall runs, which is consistent with the aforementioned segment discovered at the edge of the slope where the church is located, and also by the considerable width of the wall, at $1.60 \mathrm{~m}$ (Rogaczewska 2008a; 2008b).

In 2009, non-invasive investigations using ground-penetrating radar were conducted in the area of Saint Stanislaus the Bishop and Martyr Church in Czeladź and its immediate surroundings. These investigations were carried out by W. Nawrocki, W. Antosiewicz and J. Pieczonka acting on behalf of the Institute of Non-Destructive Testing of KPG Sp. z o.o. Their main goal was to verify the presence of possible remains of a medieval castle and continuation of the medieval defensive wall in the area of the church. These works were undertaken in relation to the discovery of remains of a defensive wall in the immediate vicinity of the church. This wall, as it was discovered only in a single point in the city, clearly could not have been considered a city defensive wall. Researchers assumed a working hypothesis that it might have been a peripheral wall of an unspecified defensive structure, possibly a residential and defensive tower, whose remains were located under the church floor. However, investigations inside the church did not bring about the expected result, as the floor had been reinforced with steel rods; such a structure heavily dampens electromagnetic waves, which made it impossible to penetrate the surface. Only within the church cellars, where the floors were not reinforced, was it possible to create several profiles. Although non-homogeneity of the substratum was identified, interpretation will be possible only after a survey is completed.

Research in the area surrounding the church concentrated mainly on the south-western side. Profiles, made using geophysical techniques, were meant to encompass a potential continuation 
of the foundation of the previously identified defensive wall. However, penetrating the ground proved impossible here as well, due to the presence of blast furnace slag under the paving laid around the church (Nawrocki et al. 2009).

In 2010, another fragment of the Czeladź city wall was discovered in Pieńkowskiego Street. Investigations which led to this discovery were directed by A. Rogaczewska. This discovery finally dispelled all doubts surrounding the function of the wall fragment uncovered two years earlier near Saint Stanislaus the Bishop and Martyr Church (Pierzak 2012). The archaeological works performed allowed both wall fragments to be situated along the medieval urban layout. As at the time this was the only place where fragments of a defensive wall had been found, it was hypothesised that it could have also been a wall which surrounded a defensive structure resembling a residential and defensive tower, similar to the one which existed in neighbouring Bytom. As an aside, it should be noted that further archaeological research in the region is necessary in order to verify whether Czeladź also had, in addition to the city walls, a ducal residence.

In 2016, the authors of this article performed an archaeological survey less than 70 metres east of the Market Square (Fig. 2). A $5 \times 3 \mathrm{~m}$ excavation trench was established, oriented on the east-west axis. The exploration resulted in the discovery of copings of two walls.

Remains of the first of these two walls were made of stone (Fig. 3). The wall was oriented along the north-west - south-east axis, and was interpreted as a fragment of a city wall. Its width was $1.40 \mathrm{~m}$. As only a single layer of stone survived, it was not possible to determine the bond used in its construction (Fig. 4). The wall was built using stones of various sizes, hewn only on the face side. The wall was added to another wall (Fig. 5), $0.60 \mathrm{~m}$ wide at the foundation; however, this wall was sunk into a compact layer of marl and clay, which reinforced it from the inner side. It is highly probable that the above-ground part of the wall was of the same width as the segment discovered on the outer side of the church.

The second discovered wall remains were also made of stone. The wall was oriented on the south-east - north-west axis. It was over $0.80 \mathrm{~m}$ wide, $2.07 \mathrm{~m}$ long and was preserved up to a height of $0.47 \mathrm{~m}$. Five stone layers survived. These remains were interpreted as the southern part of the eastern city gate. They were destroyed in the eastern part of the survey site by a cut made most likely in the $16^{\text {th }}$ century. Two fragments of earthenware were discovered in the fill of this cut, dated to, respectively, between the $15^{\text {th }} / 16^{\text {th }}$ centuries and the $16^{\text {th }}$ century. This material allows the post quem date of the cut to be determined as the $16^{\text {th }}$ century.

A lime and sand mortar was used in the construction of both walls. This mortar is characterized by a grey and beige colouration and an admixture of significant amounts of sand, limestone lumps, small brick fragments and charcoals. These admixtures were used in the Medieval Period; this opinion was confirmed by a renowned researcher of medieval architecture, W. Niewalda from the Design and Research Services Workshop, who, after conducting a comparative analysis of a collected sample of the mortar, dated it to the $14^{\text {th }} / 15^{\text {th }}$ century.

After a cartographic analysis of early modern city plans and overlaying plans from these excavations on the aforementioned early modern plans, it has to be said that the discovered walls do not fit into the layout of other buildings (Krasnowolski 2013). It should also be noted that the discovered walls are positioned diagonally to the border of the plot.

The above arguments and the fact that the walls are located on the axis of Rynkowa Street, which leads to the Market Square, are enough to establish that these wall remains are remnants of city fortifications, namely of a city wall and of the eastern city gate, which led to Będzin, and further to Cracow (Fig. 2). The opening of the presumed gate lies on the same axis as the exit from Rynkowa Street. 


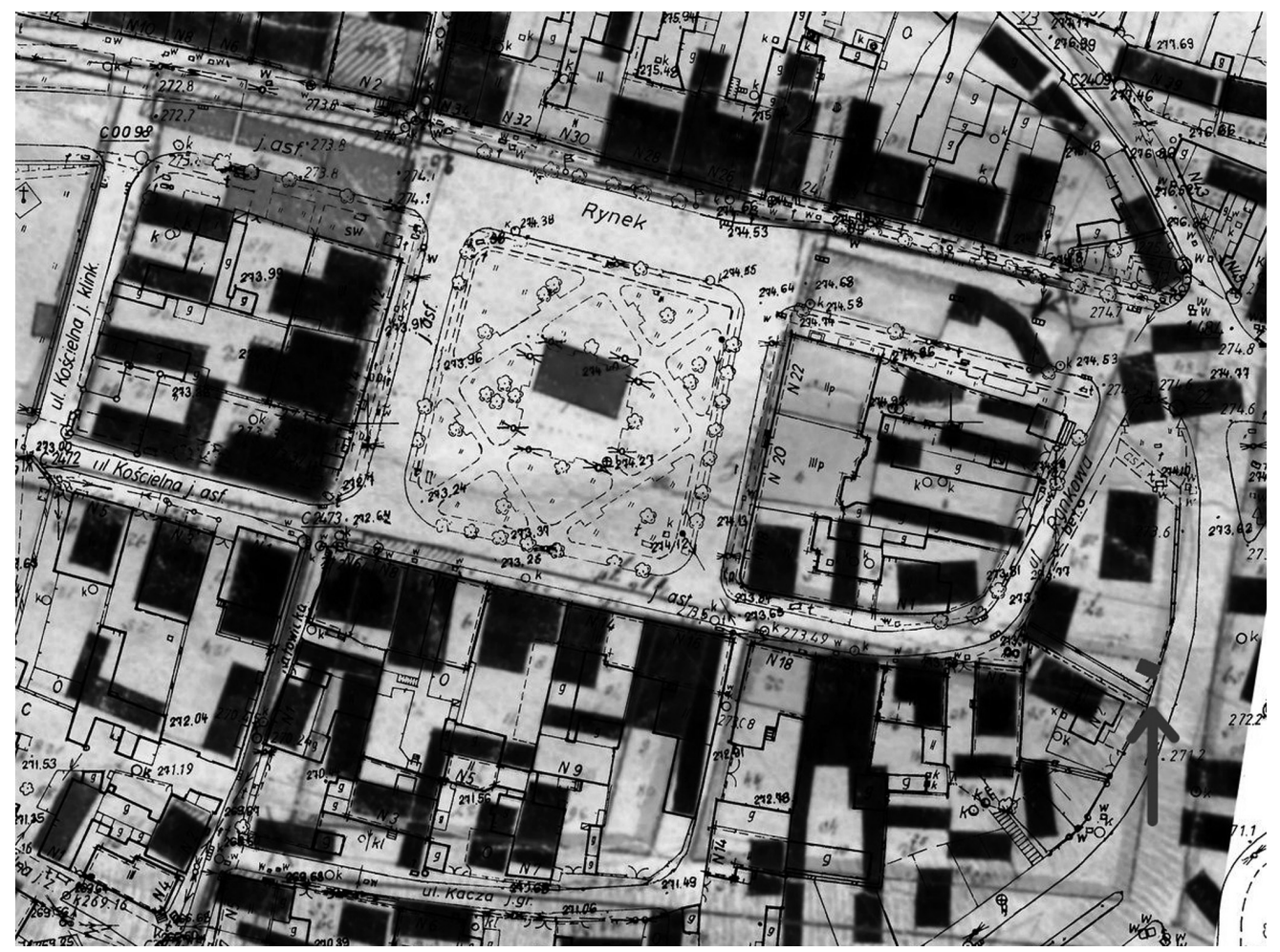

Fig. 2. Location of archaeological survey trenches on the map of Czeladź centre

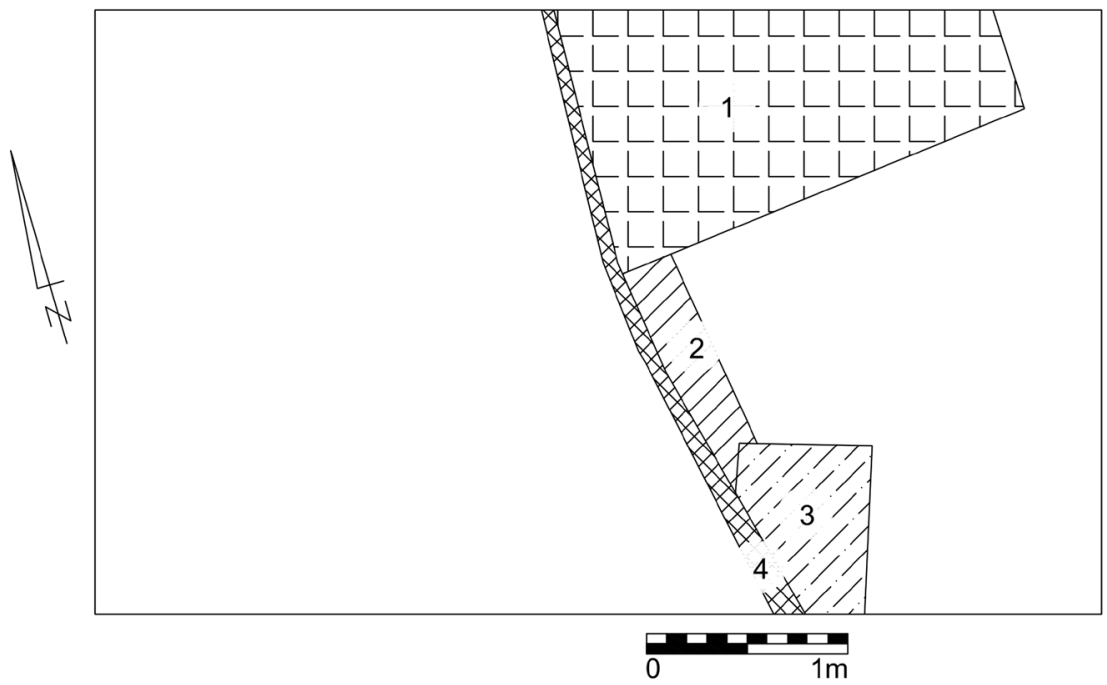

Fig. 3. Plan of the 2016 excavation trench. 1 - remains of the city gate, 2 - remains of the defensive wall, 3 - modern well drainage, 4 - modern sewage pipe 


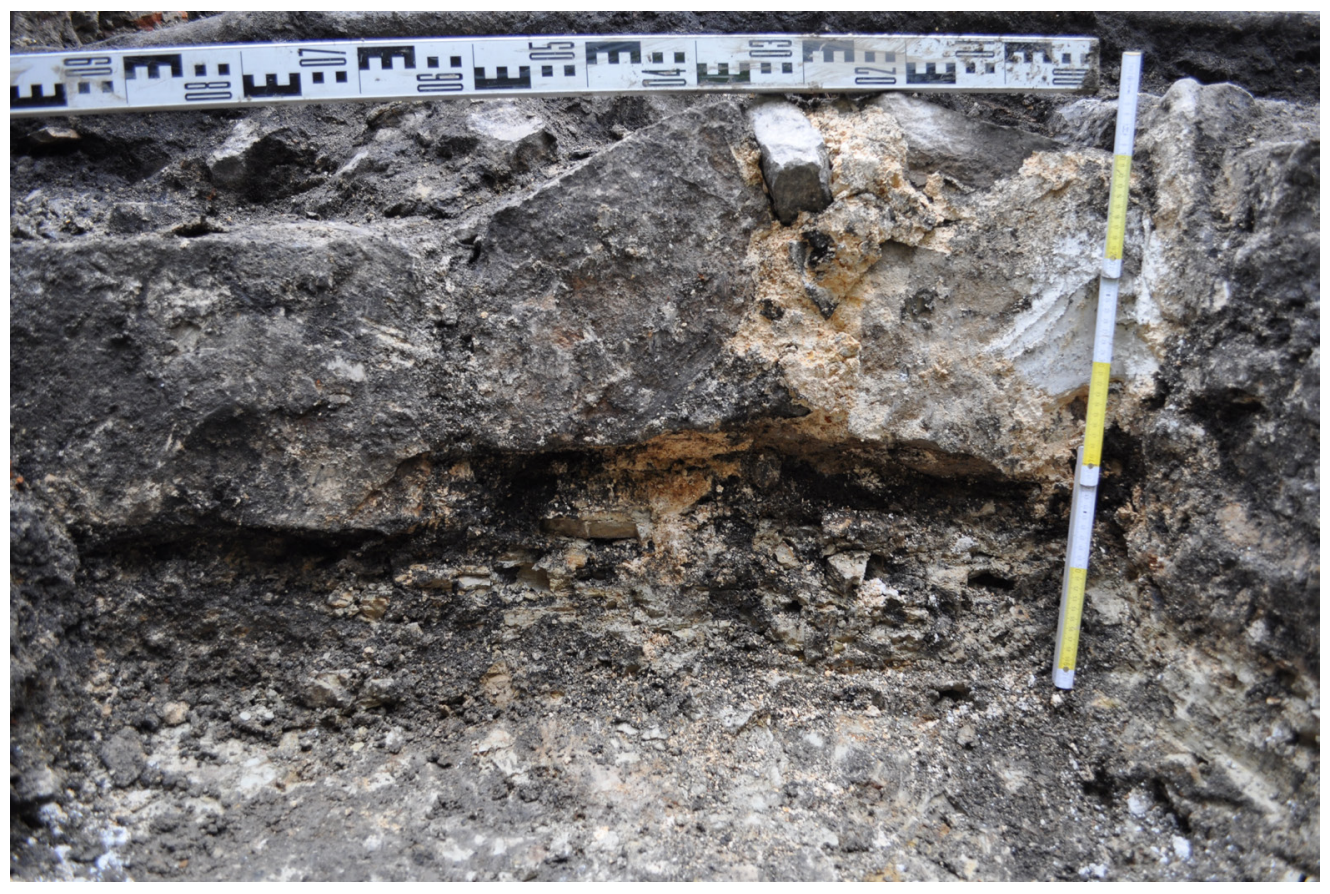

Fig. 4. Remains of the wall

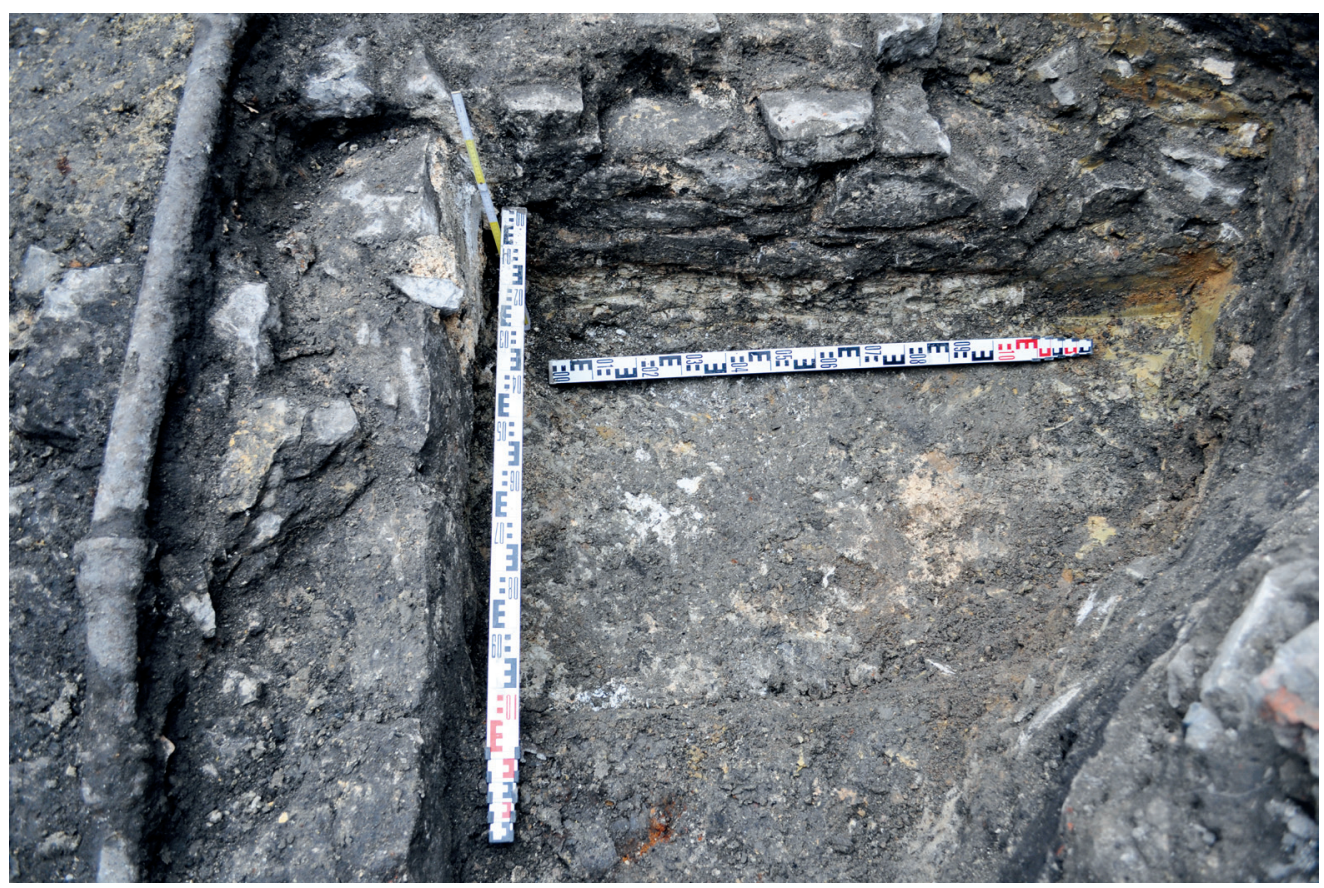

Fig. 5. Remains of the city gate (up), and remains of the defensive wall (left) 
The question of the founder of the Czeladź city wall deserves a separate discussion. The technique used in the wall's construction, as well as its considerable width, point to the second half of the $13^{\text {th }}$ century or the beginning of the $14^{\text {th }}$ century. The founder was most likely Casimir II of Bytom, who after 1281 built a castle in neighbouring Bytom and surrounded that city with a defensive wall (Gramer 1864). During that period, Czeladź was part of the Duchy of Bytom. As Casimir II of Bytom paid homage to Wenceslaus II of Bohemia (on 10 January 1289), Czeladź was a border city. The duke most likely surrounded it with a defensive wall. As an aside, it should be noted that defensive city walls were usually not built immediately, at the moment the city was founded (Pierzak 2004, 187-188). The closest analogy would be Bytom, which is not far from Czeladź. That city, chartered under the German law by Władysław, the Duke of Opole, in 1254 (Drabina et al. 1985), had no stone or brick fortifications during the initial stages of its development. There is a view in literature that at that time Bytom had wooden and earthen fortifications (Horwat 1988, 44). However, archaeological research has not confirmed this hypothesis. Only Casimir II, duke of the partitioned lands of Bytom and Koźle, surrounded the city with walls. All evidence seems to indicate that he fortified Czeladź as well.

Indications that Czeladź had city walls have long been known from the annals of the Bishops of Cracow (Piekosiński 1876; 1879 [1965]). However, for many years, there was no clear archaeological evidence which would confirm their existence. Archaeological works carried out by A. Rogaczewska at the end of the first decade of the $21^{\text {st }}$ century were of particular significance. They resulted in the discovery of walls dated to the Medieval Period in the northern and south-western parts of the city. However, it was still unclear whether Czeladź was actually fortified and what course the city wall span along. Only the research conducted in 2016 provided answers to some of these questions by uncovering a fragment of a city gate and walls. They definitely confirmed that the entire city was surrounded by walls.

\section{Brama i mury miejskie w Czeladzi w świetle badań archeologicznych}

Niniejszy artykuł ma na celu zaprezentowanie problematyki bramy miejskiej oraz murów obronnych miasta Czeladzi przez pryzmat najnowszych badań archeologicznych Jeszcze do niedawna w powszechnej opinii, Czeladź uchodziła w średniowieczu za miasto „otwarte”, nie posiadające murowanych umocnień obronnych. Przekonanie to utrwalało się zarówno poprzez brak źródeł historycznych, pochodzących z epoki, jak i niedostateczny stan badań archeologicznych.

Pierwsze badania wykopaliskowe związane z tym zagadnieniem odbyły się w 1997 i 1998 roku. Prowadzone były przez zespół z Pracowni Dokumentacji Archeologiczno-Konserwatorskiej z Łodzi. Pomimo zakrojonych na szeroką skalę badań nie udało się odnotować reliktów murów miejskich starszych niż XVII wiek, zarówno z terenu placu kościoła św. Stanisława Biskupa i Męczennika, jak i rejonu muru oporowego wzmacniającego skarpę przy tej świątyni. Kolejne prace badawcze, związane z poszukiwaniem muru miejskiego, przeprowadzono w 2005 roku, w południowo-wschodniej części miasta. Badaniami kierował A. Andrzejewski z Uniwersytetu Łódzkiego. Podejrzewano, iż we wschodniej części znajdować się mogą relikty bramy miejskiej, natomiast w części południowej miasta spodziewano się istnienia muru obronnego. Niestety, również i te badania nie przyniosły spodziewanego efektu.

Znaczącego postępu w badaniach nad problematyką murów miejskich w Czeladzi przyniosły dopiero prace archeologiczne prowadzone w 2008 roku przez A. Rogaczewską z Muzeum Zagłębia w Będzinie. Odkryła ona w południowo-zachodniej partii kościoła św. Stanisława Biskupa i Męczennika oraz w północnej 
części Starego Miasta odcinki murów, datowanych na okres średniowiecza. Autorzy badań sugerują, iż drugi z wymienionych murów powstał w końcu XIII lub na początku XIV wieku, w okresie, gdy Czeladź znajdowała się w obrębie Księstwa Bytomskiego, za czasów księcia Kazimierza II bytomskiego. Prowadzone w tym samym roku przez A. Rogaczewską nadzory archeologiczne przy skarpie kościoła ujawniły kolejne trzy fragmenty średniowiecznych murów. Jednakże dopiero badania Rogaczewskiej z 2010 roku przy ulicy Pieńkowskiego udowodniły ostatecznie, iż Czeladź była otoczona murami miejskimi.

W 2016 roku autorzy niniejszego tekstu przeprowadzili badania archeologiczne $70 \mathrm{~m}$ na wschód od rynku. W ich trakcie natrafiono na relikty dwóch murów. Pierwszy, wykonany z kamienia, zorientowany został na osi północny-zachód - południowy-wschód. Mur ten miał 1,40 m szerokości. Ze względu na fakt, iż zachowała się tylko jedna warstwa kamieni, nie można ustalić w jakim wątku został wykonany. Do budowy muru użyto kamieni o różnych wielkościach, ociosanych jedynie od strony lica. Mur ten dostawiony był do drugiego muru, który w warstwie fundamentowej miał szerokość $0,60 \mathrm{~m}$, został jednak wkopany w zbitą warstwę gliny z marglem, która po wewnętrznej stronie muru stanowiła jego wzmocnienie. Odkryty relikt drugiego muru wykonany był również z kamienia. Zorientowany był na osi NW-SE. Miał ponad 0,80 m szerokości, ponad 2,07 m długości i zachował się do wysokości 0,47 m. Zachowało się pięć warstw kamienia. Relikt ten został zaburzony we wschodniej części sondażu przez wkop pochodzący najprawdopodobniej z XVI w. W zasypisku tego wkopu odkryto dwa fragmenty naczyń glinianych, z których pierwszy jest datowany na przełom XV/XVI wieku, a drugi na XVI wiek. Materiał ten pozwala datować wkop post quem na XVI wiek.

Oba mury posiadały zaprawę wapienno-piaskową. Zaprawa ta wyróżnia się barwą szaro-beżową oraz domieszką znacznej ilości piasku, grudek wapna, drobnych fragmentów cegieł oraz węgli drzewnych. Domieszki te używane były w okresie średniowiecza. Opinię tą potwierdził W. Niewalda z pracowni Usługi Projektowo-Badawcze z Krakowa, datując próbkę zaprawy wiek XIV lub XV.

W wyniku analizy architektonicznej oraz kartograficznej należy stwierdzić, iż relikty tych murów są pozostałością elementu fortyfikacji miejskich, muru miejskiego oraz fragmentu wschodniej bramy miejskiej, prowadzącej w stronę Będzina i dalej do Krakowa. Światło domniemanej bramy usytuowane jest na wylot ulicy Rynkowej.

Badania te dały kolejny dowód na to, iż Czeladź posiadała mury obronne. Wykazały także po raz pierwszy w źródłowym materiale archeologicznym obecność bramy miejskiej.

\section{References}

Andrzejewski A., 2005 Sprawozdanie z badań archeologiczno-architektonicznych w Czeladzi, gm. loco, pow. Będzin przeprowadzonych w 2005 roku, Łódź (typescript in the Archive of the National Service of Monuments Protection in Katowice).

Andrzejewski A., Grabarczyk T., Lewandowski M., 1998 Sprawozdanie z badań archeologicznych w Czeladzi w woj. katowickim, prowadzonych w 1997 i 1998 roku, Łódź (typescript in the Archive of the National Service of Monuments Protection in Katowice).

Drabina J., Horwat J., Jedynak Z., 1985 Bytom średniowieczny. Przekazy źródłowe 1123-1492, Opole.

Dziurla H., 1965 Czeladź. Studium historyczno-urbanistyczne miasta. Pracownia Dokumentacji Naukowo-Historycznej PKZ, Kraków (typescript in the Archive of the National Service of Monuments Protection in Katowice). 
Gramer F., 1864 Chronik der Stadt Beuthen, Beuthen.

Horwat J., 1988 Dawne fortyfikacje miejskie, Zabytki Bytomia, Magazyn Bytomski 7. 1996 Formowanie się miast księstwa opolsko-raciborskiego do połowy XIV w., Gliwice.

Inwentarz dóbr biskupstwa krakowskiego, 1668, Archiwum Kapituły Katedralnej, rkps Libri Archivi.

Kozaczewski T., 1989 Przejście od miasta wczesnośredniowiecznego do miasta średniowiecznego, Śląski Kwartalnik Historyczny Sobótka, 44 (4), pp. 511-526.

Krasnowolski B., 2013 Rola analiz układów przestrzennych $w$ badaniach dziejów miast $i$ wsi. Rozważania metodologiczne, Teka Komisji Urbanistyki i Architektury Oddział PAN w Krakowie, 41, pp. 139-153.

Lukas E., 1974 Średniowieczne mury miejskie na Pomorzu Zachodnim, Poznań.

Malik R., 2010 Czeladź. Ze studiów nad budowa i kształtem miasta średniowiecznego, Kwartalnik Architektury i Urbanistyki, 55 (3), pp. 3-12.

Nawrocki N., Antosiewicz W., Pieczonka J., 2009 Badania georadarowe w kościele pw. św. Stanisława Biskupa i Męczennika w Czeladzi $i$ w jego otoczeniu, Kraków (typescript in the Archive of the National Service of Monuments Protection in Katowice).

Piekosiński F., (ed.), 1876 Kodeks dyplomatyczny Małopolski (Vol. 1), Kraków: Akademia Umiejętności.

Piekosiński F., 1879 Kodeks dyplomatyczny miasta Krakowa: 1257-1506. Część 1, Wydawnictwa Komisji Historycznej Akademii Umiejętności w Krakowie 13, Monumenta Medii Aevi Historica Res Gestas Poloniae Illustrantia 5, Kraków (reprint 1965: New York - Warszawa).

Pierzak J., 2004 Miejskie mury obronne na Górnym Śląsku na przykładzie Bytomia, Bielska-Białej, Żor i Gliwic, (in:) M. Machnik (ed.), Początki i rozwój miast Górnego Śląska. Studia interdyscyplinarne, Seria Monograficzna 10, Muzeum w Gliwicach, Gliwice, pp. 187-214.

2012 Badania archeologiczne w Czeladzi, (in:) J. Drabina (ed.), Historia Czeladzi 1, Czeladź.

Rajman J., 2012 Czasy księcia opolskiego Władysława (1246-1281/82), (in:) J. Drabina (ed.), Historia Czeladzi 1, Czeladź.

Rogaczewska A., 2008a Sprawozdanie z badań archeologicznych w Czeladzi na Starym Mieście za okres lat 2006 i 2007. Wyniki badań archeologicznych przy budowie kanalizacji sanitarnej i przebudowie wodociagu w Czeladzi w latach 2006, 2007, Katowice (typescript in the Archive of the National Service of Monuments Protection in Katowice).

2008b Sprawozdanie z badań archeologicznych $w$ Czeladzi na skarpie kościoła p.w. Św. Stanisława Biskupa w lipcu-sierpniu 2008, Katowice (typescript in the Archive of the National Service of Monuments Protection in Katowice).

Widawski J., 1973 Miejskie mury obronne w państwie polskim do początku XV wieku, Warszawa. 